\title{
Role of E-Market in Marketing of Handloom Products: A Study on Cuttack District of Odisha
}

\section{OPEN ACCESS}

Manuscript ID:

COM-2021-09023744

Volume: 9

Issue: 2

Month: April

Year: 2021

E-ISSN: 2582-6190

Received: 22.01.2021

Accepted: 09.03.2021

Published: 01.04.2021

Citation:

Patra, Samira. "Role of E-Market in Marketing of Handloom Products:

A Study on Cuttack

District of Odisha."

ComFin Research, vol. 9, no. 2, 2021, pp. 19-24.

\section{DOI:}

https://doi.org/10.34293/ commerce.v9i2.3744

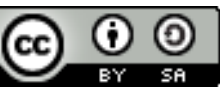

This work is licensed under a Creative Commons Attribution-ShareAlike 4.0 International License

\author{
Samira Patra \\ Assistant Professor and Head, Department of Commerce \\ Model Degree College, Nayagarh, Odisha, India \\ http://orcid.org/0000-0002-1879-8933
}

\begin{abstract}
Introduction: Handloom Industry provides a large number of employment to the rural and semirural people of India and Odisha. Handloom weavers of Odisha produce various handloom products, which have demands in the national and international market for their quality and design. The Handloom Industry of Odisha is one of the oldest ways to earn bread among the people. It is always remained famous for producing World famous products like "Katki saree", "Sambalpuri Saree", various silk sarees, Tassar Saree, Tie-dye, Bomkai Cotton, glossy khanduas, "Gamchas", furnishing and Handicrafts. The innovative weavers, with their skillful blending of myths, faiths, symbols and imagery, provide the appealing fabric dynamism. So far as designing and techniques are concerned, it varies from double ikat (tie and dye) involving highly intricate designs woven by the Bhulia weavers of undivided Sambalpur, Bolangir, Kalahandi and Phulbani districts (such as Pasapalli, Bichitrapuri, etc.) to single ikat woven in Maniabandha, Nuapatna area of Cuttack district (Khandua designs) to extra warp and weft designs like Bomkai, the silk of Berhampur, the cotton of Khurda district, vegetable-dyed fabrics of Kotpad (Koraput district), fine count sarees of
\end{abstract} Jagatsinghpur and Tassar fabrics of Gopalpur, Fakirpur in Kendujhar district.

Odisha handlooms have a rich tradition. Its 'Tie \& Dye' patterns are world-famous. Their Tie \& Dye patterns are popularly known as 'IKAT'. The Ikat technique is commonly known as "BANDHA" in Odisha. Handloom weavers of Odisha produce various types of fabrics such as sarees (which constitute the major component), dress materials, scarfs, dhotis, towels, other fabrics of day-today use such as wall hangings, etc. In the technologically driven society, handloom products are trading over the e-marketing/virtual platform like Amazon, Flipkart etc.

Research Gap: Numerous researches have been undertaken by researchers about the handloom Industry and handloom Weavers of Odisha. But, no such studies have been conducted on the role of e-market in the marketing of handloom products of Cuttack district of Odisha.

Objective of the Study: This paper attempt to study the role of the e-market in the marketing of handloom products in Cuttack district of Odisha.

Research Methodology:

i) Nature of data: This present study is based on both primary data and secondary data.

ii) Sample Size: The sample data size consists of 100 respondents in the Cuttack District.

iii) Sources of Primary Data: Primary data have been collected through a well-defined questionnaire and direct interview methods from 100 respondents (including handloom weavers, Students, Housewife, Businessman and Academician) Cuttack District.

iv) Sources of Secondary Data: The secondary data have been collected from various secondary sources like journals, magazines, and various reputed websites. The collected data have been classified and tabulated according to the requirements of the study.

v) Statistical Tools: There are various statistical tools like mean, Chi-Square Test, Multi Correlation, Llikert 5 points scale etc have been used for the analysis and interpretation of results.

Conclusions: Handloom Products still have demand in the national and international market through E-market for their quality, price and design. The E-market is promoting the handloom products in the online platform, which leads to more popularity. Hence, the demands of handloom products in the technological era have a massive success for the Handloom Industry in Odisha. Thus, it may be concluded that the E-market has a significant role in the marketing of handloom products.

Keywords: E-market, Handloom products, E-marketing, Technological era, International market 


\section{Introduction}

With the use of the internet, peoples from different parts of the world are now connecting with a single platform to share their information. Information is the power. Without proper and true information, one may not get the particular thing that he/she desires. The concept of globalization made the whole world into a single market and the internet made it so easier. The world's people are now getting lots of alternative products and the best quality products at reasonable prices. There are various social networks that help people to get these things.

Business houses are now creating a virtual market for their market through advertisements on social media. This virtual or e-market has no geographical boundary and a particular place. The customers of this market are getting their needs through the only click. In the present scenario, Various Digital Market like Flipkart, Amazon, Snapdeal, Myntra, Paytm etc., are providing possibilities for the customers for different kinds of products and services at reasonable prices. Flipkart and Amazon have a more significant role in digital markets. They have the highest turnover in the past decade.

In the present technology-driven society, handloom products of Odisha still have a distinct place in the national and international market. The handloom products of Odisha have famous for their ikta design (Tie and Dye) and a picture of living creatures with the beauty of cultural heritage. The handloom products of Odisha, as well as India, also are marketing by Amazon and Flipkart. The handloom products of Odisha are getting more popular through these digital markets.

\section{Review of Literature}

The extensive literature review provides the platform for fundamentals \& research undertaken by various researchers in the particular and related area.

Humbe, V.R. (2012), in her paper "Role of Social Media in Marketing of Handloom Products", studied the role of social media in the marketing of Handloom Products. She concluded that the use of social media in marketing benefits the handloom industries by developing the awareness and benefits of the handloom products, reducing marketing expenses, increasing the sales, providing the details regarding the marketplace to purchase the handloom products and exposure towards handloom products.

Varghese, A., and Salim, M.H. (2015) in their paper "Handloom Industry in Kerala: A Study of the Marketing Issues" studied marketing issues of the handloom industry in Keral. They found that competition from the Tamil Nadu market and power loom markets seriously affected the marketing of handloom products in Kerala.

Kahtoon, S. (2016) studied the make in India Campaign to develop the Indian Handloom Market in the paper "Make in India: A Platform to Indian Handloom Market." This paper concluded that the 'Make in India' scheme gives a new lease of life to the Indian handloom industry. This scheme has opened the doors for the Indian handloom market to showcase its beauty, strength \& capabilities in the international market.

Bindra, A. (2017) studied the consumer perception for handloom Sectors in India in the Paper "Consumer Perception for Handloom Sector". This paper concluded that the knowledge of handloom is the driving force for the consumer to buy the product is true as people who knowledge tend to buy at least one piece of handloom products.

Ramana, V., et al. (2019), in their paper "An Empirical Study on Marketing of Handloom Fabrics in Andhra Pradesh (A Case Study concerning Guntur District)" studied the marketing of handloom products in Andhra Pradesh. They concluded that Handloom marketers face severe marketing problems due to inadequate government assistance, globalization, Competition from power loom products and change in customer preferences towards clothing.

\section{Research Gap}

Numerous researches have been undertaken by researchers about the handloom Industry and handloom Weavers of Odisha. But, no such studies have been conducted on the role of e-market/digital in the marketing of handloom products of the Cuttack district of Odisha.

\section{Objective of the Study}

This paper attempt to study the role of the e-market/digital market in the marketing of handloom products of the Cuttack district of Odisha. 


\section{Research Methodology}

i) Nature of data: This present study is based on both primary data and secondary data.

ii) Sample Size: The sample data size consists of 100 respondents in the Cuttack District.

iii) Sources of Primary Data: Primary data have been collected through a well-defined questionnaire and direct interview methods from 100 respondents (including handloom weavers, Students, Housewife, Businessman and Academician) Cuttack District.

iv) Sources of Secondary Data: The secondary data have been collected from various secondary sources like journals, magazines, and various reputed websites. The collected data have been classified and tabulated according to the requirements of the study.

v) Period of Study: November-December, 2019 and January 2020.

vi) Statistical Tools: There are various statistical tools like mean, Chi-Square Test, Multi Correlation, Likert 5 points scale etc., have been used for the analysis and interpretation of results.

vii) Research Hypothesis:

H0 - The Digital markets have a significant role in the marketing of handloom products in the Cuttack District of Odisha.

H1 - The Digital markets have not significant role in the marketing of handloom products in the Cuttack District of Odisha.

\section{Data Analysis and Interpretation of Result}

Profile of Sample Unit: The sample unit consists of students, housewife, handloom weavers, businessmen and Academicians of the Study area i.e. Cuttack District of Odisha (each category has an equal percentage to total sample units) including male and female. The Sample unit is 100 and it includes 50 females and 50 males. So, the respondents as regards to male and female are $50 \%$.

Table 1: Profile of the Sample

\begin{tabular}{|c|c|c|c|}
\hline Profile & $\begin{array}{l}\text { No. of } \\
\text { respondents }\end{array}$ & $\begin{array}{l}\% \text { to } \\
\text { Total }\end{array}$ & $\begin{array}{c}\text { Valid } \\
\%\end{array}$ \\
\hline \multicolumn{4}{|l|}{ Gender } \\
\hline Male & 50 & 50 & 50 \\
\hline Female & 50 & 50 & 50 \\
\hline
\end{tabular}

\begin{tabular}{|c|c|c|c|}
\hline \multicolumn{4}{|l|}{ Education } \\
\hline Secondary & 25 & 25 & 25 \\
\hline Degree & 50 & 50 & 50 \\
\hline Above Degree & 25 & 25 & 25 \\
\hline \multicolumn{4}{|l|}{ Annual Income } \\
\hline Below Rs. $1,00,000$ & 32 & 32 & 32 \\
\hline Rs. $1,00,000-5,00,000$ & 58 & 58 & 58 \\
\hline Above Rs. 5,00,000 & 10 & 10 & 10 \\
\hline \multicolumn{4}{|l|}{ Age } \\
\hline Upto 25 & 36 & 36 & 36 \\
\hline $26-40$ & 48 & 48 & 48 \\
\hline Above 40 & 16 & 16 & 16 \\
\hline \multicolumn{4}{|l|}{ Occupation } \\
\hline Student & 20 & 20 & 20 \\
\hline Housewife & 20 & 20 & 20 \\
\hline Handloom Weavers & 20 & 20 & 20 \\
\hline Academicians & 20 & 20 & 20 \\
\hline Businessman & 20 & 20 & 20 \\
\hline Total Sample $(=\mathrm{N})$ & 100 & 100 & 100 \\
\hline
\end{tabular}

Source: Collected and compiled from Field Study

Table 1 shows that out of 100 respondents, $25 \%$ have below secondary, $50 \%$ have a degree and $25 \%$ have above degree qualification. Out of 100 respondents 32\% have below Rs. 1,00,000/-, 58\% have between Rs. 1,00,000 to Rs. 5,00,000/- and only $10 \%$ have above Rs. $5,00,000 /-$ as their annual income. Out of 100 respondents, $36 \%$ have up to 25 years of age, $48 \%$ have between 26 to 40 years of age and $16 \%$ have above 40 years ago.

Perceptional Attributes of Sample respondents: Table 2 shows perceptional attributes of the sample respondents in the study area. As so far as the perceptional attributes towards the reasonable price of the different E-markets/digital markets, the test statistics chi-square test show that the null hypothesis there is no significant difference between magnitudes of reasonable price of the different E-markets/digital markets is rejected. There is a significant difference between different magnitudes of reasonable prices of the different E-markets/ digital markets. Perceptional attributes towards the durability of products of the different E-market/ digital markets, the test statistics chi-square test shows a significant difference between the durability of products of the different E-market/digital markets. 
Table 2: Perceptional Attributes of the Sample Respondents in the Study Area

\begin{tabular}{|c|c|c|c|}
\hline $\begin{array}{c}\text { Perceptional } \\
\text { Attributes }\end{array}$ & $\begin{array}{c}\text { No of } \\
\text { respondents }\end{array}$ & $\begin{array}{l}\% \text { to } \\
\text { Total }\end{array}$ & $\begin{array}{c}\text { Test } \\
\text { Statistics } \\
\text { (5\% level } \\
\text { of sig.) }\end{array}$ \\
\hline \multicolumn{4}{|l|}{ Reasonable Price } \\
\hline Amazon & 28 & 28 & \multirow{5}{*}{$\begin{array}{c}\chi^{2}=18.3 \\
\text { p value }= \\
9.4877 \\
\text { df }=4\end{array}$} \\
\hline Flipkart & 32 & 32 & \\
\hline Myntra & 17 & 17 & \\
\hline Snapdeal & 13 & 13 & \\
\hline Shopclues & 10 & 10 & \\
\hline
\end{tabular}

\section{Durable of}

\begin{tabular}{|c|c|c|c|}
\hline Amazon Products & 22 & 22 & \multirow{5}{*}{$\begin{array}{c}\chi^{2}=11.3 ; \\
\text { p value }= \\
9.4877 \\
\text { df }=4\end{array}$} \\
\hline Flipkart Products & 32 & 32 & \\
\hline Myntra Products & 18 & 18 & \\
\hline Snapdeal Products & 15 & 15 & \\
\hline Shopclues Products & 13 & 13 & \\
\hline
\end{tabular}

\section{Quality Products of}

\begin{tabular}{|c|c|c|c|}
\hline Amazon & 32 & 32 & \multirow{5}{*}{$\begin{array}{c}\chi^{2}=29.2 ; \\
\text { p value }= \\
9.4877 ; \\
d f=4\end{array}$} \\
\hline Flipkart & 34 & 34 & \\
\hline Myntra & 14 & 14 & \\
\hline Snapdeal & 12 & 12 & \\
\hline Shopclues & 8 & 8 & \\
\hline
\end{tabular}

\section{Various Features}

\begin{tabular}{|c|c|c|c|}
\hline Amazon & 37 & 37 & \multirow{5}{*}{$\begin{array}{c}\chi^{2}=36.1 ; \\
\text { p value }= \\
9.4877 ; \\
d f=4\end{array}$} \\
\hline Flipkart & 32 & 32 & \\
\hline Myntra & 12 & 12 & \\
\hline Snapdeal & 11 & 11 & \\
\hline Shopclues & 8 & 8 & \\
\hline Total Sample (N) & 100 & 100 & \\
\hline
\end{tabular}

Source: Collected and compiled from Field Study

Table 2 shows that the perceptional attributes towards the quality of products of the different E-market/digital markets, the test statistics chisquare test shows a significant difference between the quality of products of the different E-market/ digital markets. Similarly, the perceptional attributes towards the various features available by different E-market/digital markets, the test statistics chisquare test shows a significant difference between the various features available by different E-market/ digital markets.
Ranking of Selected Digital Markets by Sample Respondents: Table 3 shows the ranking of 5 selected Digital Markets according to their buying perception. Rank 1 implies 1st preference to e-market, which has more contribution towards marketing of handloom products, followed by rank 2, rank three and so on. Out of 100 respondents, $32 \%$ prefer 1 st preference to flipkart the e-market which has more contribution towards marketing of handloom products, $29 \%$ prefer as their 2nd preference, $23 \%$ prefer as their 3rd preference, $11 \%$ prefer as their 4 th preference and only $05 \%$ prefer as their 5th preference. Out of 100 respondents, $27 \%$ prefer 1st preference to Amazon the e-market which has more contribution towards marketing of handloom products, $26 \%$ prefer as their 2 nd preference, $21 \%$ prefer as their 3 rd preference, $14 \%$ prefer their 4 th preference and $12 \%$ prefer as their 5 th preference. Similar to other E-markets/digital markets as mentioned in table no 3 .

Table 3: Ranked of Products by Likert 5 Point

\begin{tabular}{|c|c|c|c|c|c|c|c|c|}
\hline \multicolumn{9}{|c|}{ Scale } \\
\hline Rank & 1 & 2 & 3 & 4 & 5 & हैँ & تేّ & 兰 \\
\hline $\begin{array}{l}\text { Digital } \\
\text { Markets }\end{array}$ & \multicolumn{5}{|c|}{ No. of Respondents } & & & \\
\hline Amazon & 27 & 26 & 21 & 14 & 12 & 100 & 342 & 2 \\
\hline Flipkart & 32 & 29 & 23 & 11 & 5 & 100 & 372 & 1 \\
\hline Myntra & 14 & 12 & 15 & 30 & 29 & 100 & 252 & 5 \\
\hline $\begin{array}{l}\text { Snap } \\
\text { deal }\end{array}$ & 12 & 15 & 17 & 26 & 30 & 100 & 253 & 4 \\
\hline $\begin{array}{l}\text { Shop } \\
\text { clues }\end{array}$ & 15 & 18 & 24 & 19 & 24 & 100 & 281 & 3 \\
\hline $\begin{array}{l}\text { Sample } \\
\text { Size }\end{array}$ & 100 & 100 & 100 & 100 & 100 & 1000 & 1500 & \\
\hline
\end{tabular}

Source: Collected and compiled from Field Study

From table 3 as per Likert 5 point scale of ranking the selected handloom products, It is evident that out of 100 respondents, majority of them prefer 1st preference to Flipkart for most contribution towards marketing of handloom products in digital platform, 2nd preference to Amazon, 3rd preference to Shopclues, 4th preference to Snapdeal and 5th preference to Myntra. Thus Flipkart and Amazon are more popular \& contribute towards the marketing of handloom products in digital markets / e-markets. 
Testing of Hypothesis

$\mathbf{H}_{0}$ - The Digital markets have a significant role in the marketing of handloom products in the Cuttack District of Odisha.

$\mathbf{H}_{1}$ - The Digital markets have not significant role in the marketing of handloom products in the Cuttack District of Odisha.

Table 4: Data for Hypothesis

\begin{tabular}{|l|c|c|}
\hline $\begin{array}{c}\text { Digital } \\
\text { Markets }\end{array}$ & $\begin{array}{c}\text { Percentage of } \\
\text { Respondents } \\
\text { prefer to buy } \\
\text { Handloom } \\
\text { Products from } \\
\text { Digital Market }\end{array}$ & $\begin{array}{c}\text { Percentage of } \\
\text { Respondents } \\
\text { prefer to buy } \\
\text { Handloom } \\
\text { Products from } \\
\text { Physical Market }\end{array}$ \\
\hline Amazon & 77 & 23 \\
\hline Flipkart & 89 & 11 \\
\hline Myntra & 68 & 32 \\
\hline Snapdeal & 53 & 47 \\
\hline Shopclues & 41 & 59 \\
\hline
\end{tabular}

Source: Collected and compiled from field study

Table 4 shows the data collected and compiled from the field study for the Hypothesis.

Table 5: Computation of Correlation for Hypothesis 2

\begin{tabular}{|c|c|c|}
\hline & $\begin{array}{c}\text { Percentage of } \\
\text { Respondents } \\
\text { prefer to buy } \\
\text { Handloom } \\
\text { Products } \\
\text { from Digital } \\
\text { Market }\end{array}$ & $\begin{array}{c}\text { Percentage of } \\
\text { Respondents } \\
\text { prefer to buy } \\
\text { Handloom } \\
\text { Products } \\
\text { from Physical } \\
\text { Market }\end{array}$ \\
\hline $\begin{array}{c}\text { Percentage of } \\
\text { Respondents prefer } \\
\text { to buy Handloom } \\
\text { Products from } \\
\text { Digital Market }\end{array}$ & 1 & \\
\hline $\begin{array}{c}\text { Percentage of } \\
\text { Respondents prefer } \\
\text { to buy Handloom } \\
\text { Products from } \\
\text { Physical Market }\end{array}$ & -1 & \\
\hline
\end{tabular}

Source: Author's Calculation based on field study

Table 5 shows that the Correlation between the Percentage of Respondents who prefers to buy handloom products from Digital Market and Percentage of Respondents prefer to buy handloom products from Physical Market is -1.00 which shows the perfect negative correlation.

\section{Decision on Hypothesis}

Hence the decision of the research hypothesis is that Reject $\mathbf{H}_{1}$ i.e. the Digital markets have not significant role in the marketing of handloom products in the Cuttack District of Odisha and Accept $\mathbf{H}_{\mathbf{0}}$ i.e. the Digital markets have a significant role in the marketing of handloom products in the Cuttack District of Odisha. Thus, the research hypothesis concluded that the Digital markets have a significant role in the marketing of handloom products in the Cuttack District of Odisha.

\section{Key Findings}

- The Handloom products still have demand in the present technology-driven society and modern market.

- The perceptions of respondents are positive towards handloom products due to quality and durability.

- The markets of handloom products i.e., E-markets have a significant role in the State and study area.

\section{Conclusions}

Handloom Products still have demand in the national and international market through E-market for their quality, price and design. The E-market is promoting the handloom products on the online platform which leads to more popularity. Hence, the demands of handloom products in the technological era have a massive success for the Handloom Industry in Odisha. Thus, it may be concluded that the E-market has a significant role in the marketing of handloom products.

\section{References}

Bindra, Anahita. Consumer Perception for Handloom Sector. National Institute of Fashion Technology, 2017.

Chawala, Deepak, and Neena Sondhi. Research Methodology: Concept and Cases. Vikas Publishing House, 2011.

Economic Survey 2012-13, Government of Odisha. Handloom Census of India 2009-10. National Council of Applied Economic Research, 2010. 
Humbe, Veena R. "Role of Social Media in Marketing of Handloom Products." International Journal of Science and Research, vol. 3, no. 7, 2014, pp. 136-139.

Indian Handloom Industry - Position Paper. FICCI Ladies Organisation, 2019.

Joseph Nelson, D. Marketing Strategies of Handloom Weavers' Co-Operative Societies An Assessment. Gandhiram Rural University, 2001.

Kahtoon, Sabiha. "Make in India: A Platform to Indian Handloom Market." IOSR Journal of Business and Management, vol. 18, no. 9, 2016, pp. 36-40.

Kothari, C.R., and Gaurav Garg. Research Methodology: Methods and Techniques. New Age International Publishers, 2014.

Mahendra Kumar, K. An Analysis of Production and Marketing of Handloom Fabrics in Andhra Pradesh - A study of Prakasham District. Acharya Nagarjuna University, 2010.

Meher, R.K. Problems and Prospectus of Handloom Industry in Odisha, 1992.

Mohanty, M., etal.Fundamental of Entrepreneurship. Kalyani Publishers, 2016.

Pand, N.M. Activity Based Costing for Indian Industries. Mittal Publications, 1999.

Patri, D.N., and D. Patri. Business Statistics. Kalyani Publishers, 2009.

Prasada Rao, Y. Marketing Practices in Handloom Industry - A Case Study with Reference to Kurnool District. Sri Krishna Devaraya University, 2000.

Prusty, Jnana Ranjan. Conflicting Technological Systems in Textile Industry: A Study of
Selected Handloom \& Powerloom Industry in Odisha. Indian Institute of Technology Guwahati, 2013.

Rath, Navaneeta, and Sasmita Panda. "Traditional Hand-woven Khandua of Nuapatna and Maniabandha - A Navigation into its Ancestry and Analyzing the Present." IJARIIE, vol. 3, no. 4, 2017, pp. 2741-2752.

Report of the Concurrent Evaluation Study of RLTAP in KBK Districts. NABCONS Orissa Regional Office.

Report of the Steering Committee on Handlooms and Handicrafts Constituted for the Twelfth Five Year Plan (2012 - 2017). Planning Commission, Government of India, 2012.

Soundarapandian, M. Growth and Prospectus of Handloom Sector in India. NABARD, 2002.

Varghese, Anu, and M.H. Salim. "Handloom Industry in Kerala: A Study of the Marketing Issues." International Journal of Business and Administration Research Review, vol. 1, no. 11, 2015, pp. 313-317.

Venkata Ramana, J., et al. "An Empirical Study on Marketing of Handloom Fabrics in Andhra Pradesh (A Case Study with Reference to Guntur District." International Journal of Innovative Technology and Exploring Engineering, vol. 8, no. 8, 2019, pp. 10711075.

Vijaya Bhaskar, R. Marketing of Handloom Fabrics in Nellore district of Andhra Pradesh. Sri Venkateswar University, 2006.

www.texmin.nic.in

www.cuttack.nic.in

www.handloom.odisha.gov.in

\section{Author Details}

Dr. Samira Patra, Assistant Professor and Head, Department of Commerce, Model Degree College, Nayagarh, Odisha, India, Email ID: spandsp2010@gmail.com 